\title{
Biologic Width Considerations in Crown Lengthening Surgical Procedures: A Case Report
}

\author{
Adrianus Wicaksono ${ }^{1 *}$, Sri Lelyati C Masulili ${ }^{2}$ \\ ${ }^{1}$ Department of Periodontics, Faculty of Dentistry, University of Prof. DR. Moestopo (Beragama), \\ Jakarta, Indonesia \\ ${ }^{2}$ Departement of Periodontics, Faculty of Dentistry, Universitas Indonesia, Jakarta, Indonesia \\ *Email: drg.adrianuswicaksono@gmail.com
}

\begin{abstract}
Crown lengthening is an adjunctive procedure used in restorative dentistry to treat cases of subgingival caries requiring exposure of healthy tooth structures and reconstruction of biologic width. A 54-year-old female patient came for crown lengthening of the lower right teeth. The patient had good oral hygiene and was referred from prosthodontia, where teeth 44 and 45 had been treated with root canals. Clinical examination results showed tooth 45 in the form of residual roots with no tooth mobility and a 3-mm pocket depth. Radiological examination showed good root canal filling, a good crown-to-root ratio, and no radiolucency in the apical part. The diagnosis of this case was localized chronic periodontitis. Crown lengthening with alveolar bone removal was performed to achieve satisfactory biologic width and the ferrule effect. No complaints were made by the patient after the surgical procedure. Installation of splinted crowns on teeth 44 and 45 will. The results of this case report indicate that crown lengthening accompanied by bone removal can be performed to achieve an appropriate biologic width and the ferrule effect, both of which are needed for restoration.
\end{abstract}

Keywords: biologic width, crown lengthening, bone removal, ferrule effect

\section{Introduction}

The ideal anterior gingiva includes healthy periodontal tissue and is free from inflammation. Ingber et al. (1977) observed that the presence of caries or restorations near the alveolar crest can cause inflammation and bone loss due to biologic width violance. Therefore, the margin of restoration has been suggested to be at least $3 \mathrm{~mm}$ more coronal than the alveolar crest; this margin can be achieved by the surgical approach known as crown lengthening. Crown lengthening is performed to increase the length of the clinical crown; it acts as an adjunctive procedure in restorative dentistry in cases where subgingival caries require the exposure of healthy dental structures and biologic width reshaping.

The total distance from the alveolar crest to the gingival margin is about $3 \mathrm{~mm}$, which includes $0.69 \mathrm{~mm}$ of sulcus depth, $0.97 \mathrm{~mm}$ of epithelial attachment, and 1.07 mm of connective tissue attachment. The dimension of the soft tissue attached to the tooth portion of the coronal peak of the alveolar bone is called the biologic width 
(Fig 1). The biologic width is an average value that is influenced by individual variation, topography, and gingival biotype differences [1].

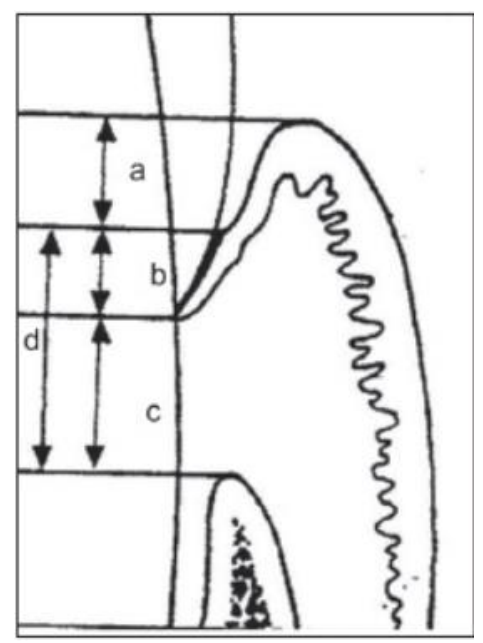

Fig 1. (a) Normal sulcus $(0.69 \mathrm{~mm})$, (b) epithelial attachment $(0.97 \mathrm{~mm})$, (c) connective tissue $(1.07 \mathrm{~mm})$, (d) biologic width $(\mathrm{b}+\mathrm{c})$

The presence of restoration margins that are too profound into the gingival sulcus may interfere with the biologic width, resulting in inflammation, attachment loss, alveolar bone destruction, and recession. Inflammatory severity is also affected by plaque control procedures and gingival biotypes [1].

Aside from restorative needs, crown lengthening is also used for aesthetic needs. The popularity of aesthetic-oriented dental care has increased significantly over time, and crown lengthening has become one of the most frequently chosen alternative treatments to improve the aesthetics of anterior teeth restoration, gummy smile conditions, or asymmetry of the gingival margins [2].

In aesthetic crown lengthening, the ratio of the length of each tooth to its width and the ratio of the length to the width between anterior teeth are important considerations. Gillen et al. (1994) defined the width of the upper anterior gear as follows: the lateral incisors are $78 \%$ of the central incisored width, the lateral incisors are $87 \%$ of the canine width, and the caninus is $90 \%$ of the central incisored width. The upper anterior teeth length ratio is expressed as follows: the lateral incisions are $82 \%$ of the central incisored length and the caninus is of the same length as the central incisor. The central incisor itself has a length-to-width ratio of 0.80 . The contour of the gingival margin should also be considered, especially in patients with high smile lines. Kokich et al (1984) found that the margins of the central incisored gingiva and caninus reside equally high while the lateral incisor margins are $1 \mathrm{~mm}$ deeper into the coronal (Fig 2) [3]. 


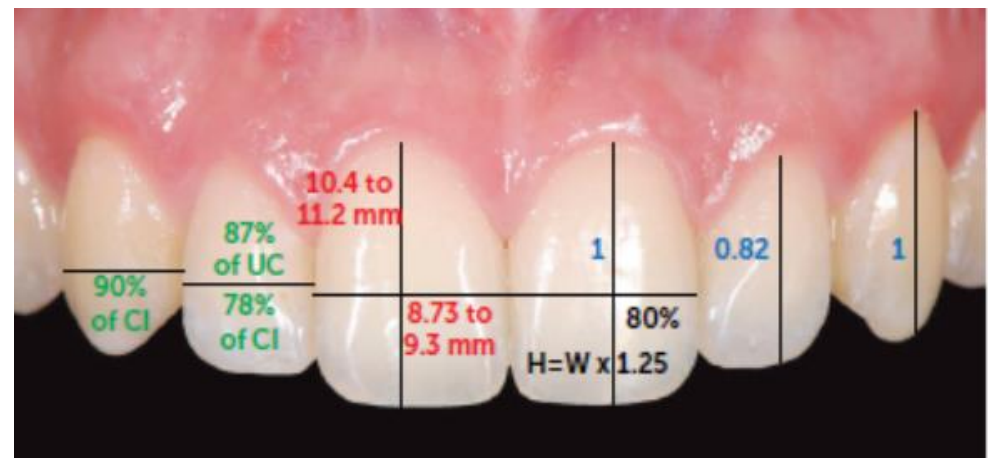

Fig 2. The proportion and Dental Dimension of Width and Length Variation on central incisor dimension (red), the ratio of length to width on central incisor (black), anterior tooth ratio (green), and anterior teeth length ratio (blue)

\section{Case and Case Management}

A 54-year-old female patient came for crown lengthening of her lower right teeth; the patient had good oral hygiene level and was referred from prosthodontia, where teeth 44 and 45 teeth had been treated with root canals. Clinical examination results revealed tooth 45 teeth in the form of residual roots with no tooth agitation and a 3 $\mathrm{mm}$ pocket depth (Table 1). Radiological examination showed good root canal filling, a good crown-to-root ratio, and no radiolusency in the apical section (Fig 3). The diagnosis of this case was localized chronic periodontitis.

Table 1. Probing depth of the pocket

\begin{tabular}{|l|l|l|l|l|l|l|}
\hline \multirow{2}{*}{ Teeth } & \multicolumn{3}{|c|}{ 45 } & \multicolumn{3}{|c|}{ 44 } \\
\cline { 2 - 7 } & Distal & $\begin{array}{l}\text { Buccal/ } \\
\text { lingual }\end{array}$ & Mesial & Distal & $\begin{array}{l}\text { Buccal/ } \\
\text { lingual }\end{array}$ & Mesial \\
\hline $\begin{array}{l}\text { Pocket Depth } \\
\text { Buccal }\end{array}$ & $2 \mathrm{~mm}$ & $2 \mathrm{~mm}$ & $1 \mathrm{~mm}$ & $2 \mathrm{~mm}$ & $2 \mathrm{~mm}$ & $3 \mathrm{~mm}$ \\
\hline PDlingual & $2 \mathrm{~mm}$ & $1 \mathrm{~mm}$ & $2 \mathrm{~mm}$ & $2 \mathrm{~mm}$ & $2 \mathrm{~mm}$ & $2 \mathrm{~mm}$ \\
\hline $\begin{array}{l}\text { Bone sounding } \\
\text { Buccal }\end{array}$ & $4 \mathrm{~mm}$ & $5 \mathrm{~mm}$ & $3 \mathrm{~mm}$ & $3 \mathrm{~mm}$ & $4 \mathrm{~mm}$ & $5 \mathrm{~mm}$ \\
\hline BS lingual & $3 \mathrm{~mm}$ & $3 \mathrm{~mm}$ & $3 \mathrm{~mm}$ & $3 \mathrm{~mm}$ & $3 \mathrm{~mm}$ & $4 \mathrm{~mm}$ \\
\hline
\end{tabular}




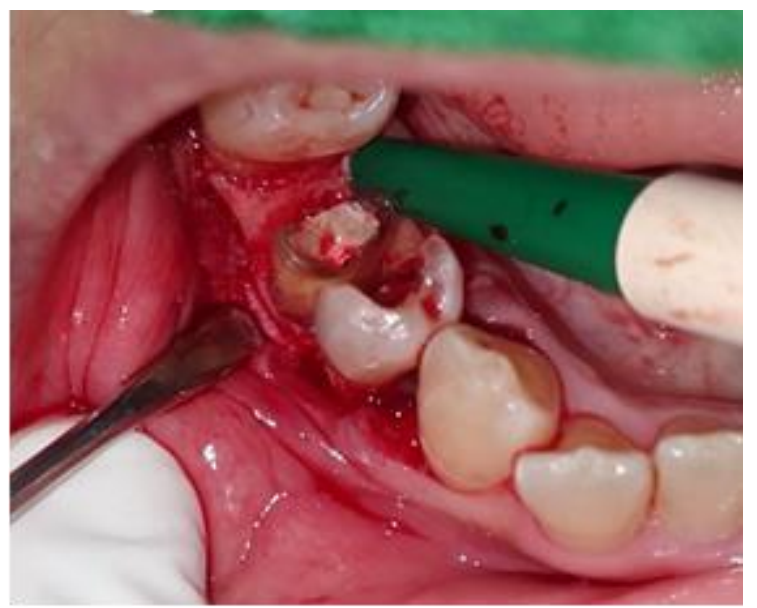

Fig 3. Radiographic photo of teeth 44 and 45 before surgery

Scaling, root planing, and oral hygiene were performed as initial therapies. Thereafter, crown lengthening surgery with $2 \%$ lidocaine $\mathrm{HCl}$ anesthesia was performed at the patient's next visit; this procedure was performed in combination with the apically positioned flap technique and ostectomy. Treatment began with an intrasulcular incision to maintain the gingival tissue for apical repositioning. A mucoperiosteal flap wth full thickness in the coronal side and partial thickness in the apical side was made. Ostectomy and osteoplasty were performed by a bone file, chisel, or bur bone (Fig 4). Following these treatments, the flap was repositioned to the apical side and then stitched (Fig 5). The first follow-up was 1 week after surgery, during which the patient reported no complaints. The second and third follow-ups were performed 2 and 3 weeks, respectively, after surgery and included radiological photography (Fig 6).

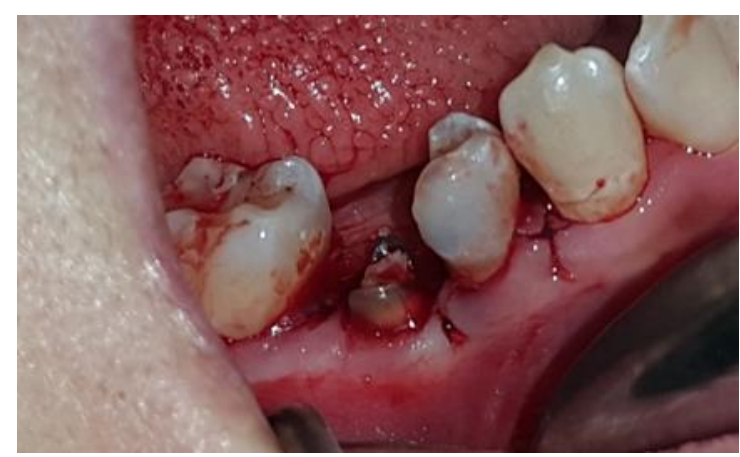

Fig 4. Crown lengthening with ostectomy of the area around teeth 44 and 45 


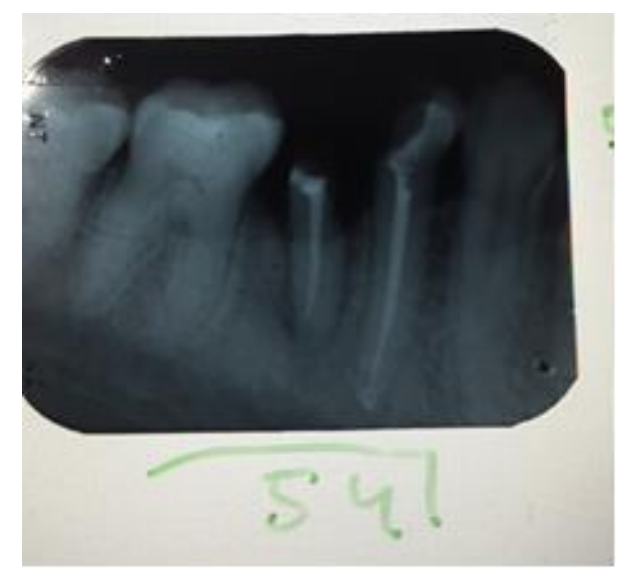

Fig 5. Apical positioning and suturing of the flap using an atraumatic 5-0 nylon

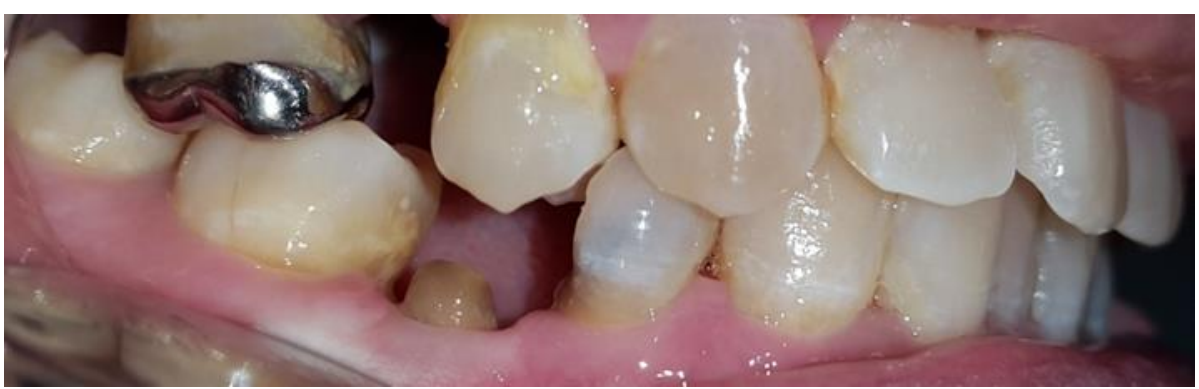

Fig 6. Radiographic and clinical photo of tooth 45 after 3 weeks

\section{Discussion}

Biologic width is a physiological seal formed around teeth and serves to protect the alveolar bone from infection and disease. Biologic width can be clinically evaluated by bone sounding, which involves probing with a local anesthesia until the top of the bone is reached. The measure of biologic width is obtained from the bone sounding measurement minus the depth of the sulcus. A measurement result of $<2$ $\mathrm{mm}$ indicates violance of the biologic width [1].

Because the biologic width is a physiological feature, the body will continuously attempt to reshape the space between the alveolar bone and the restoration margin to stimulate new attachments. If this process occurs in thin and highly scalloped gingiva, recession will occur. If this process occurs in thick and fibrous gingiva, persistent gingival inflammation may occur, although, in such cases, the bone height appears unchanged. Valderhaug and Birkeland (1976) found that changes in the subgingival margins could result in quantitative and qualitative changes in microflora, increased plaque and gingival index, recession, increased pocket depth, and production of sulcus fluid [1,7].

Libman and Nicholls (1995) suggested that 1.5-2 $\mathrm{mm}$ dental structures are required in the ferrule height of the crown to distribute the occlusion load to the 
periodontal ligament in order not to centralize on the post and core components [9]. Ferrule height provides a bracing effect between restorations and teeth, thereby increasing retention, preventing fractures, and enhancing long-term success of restoration [8].

Crown lengthening is a treatment that aims to increase the length of the clinical crown. The clinical crown is defined as the tooth portion starting from the gingival margin to the incisal or occlusal surface (American Academy of Periodontology, 1992).

\section{Conclusions}

The tissue healing period after crown lengthening determines the time of definitive restoration placement. Complete healing following completion of soft and bone tissue recontouring takes about \pm 20 weeks. Provisories can be created 2-4 weeks after surgery and left until the tissue is completely healed. When only soft tissue recounturing (i.e., gingivectomy) is performed, full recovery may be achieved within 8-10 weeks, after which definitive restorations can be placed [12].

\section{References}

1. Huynh-Ba G, Brägger U, Lang NP. Surgical lengthening of the clinical crown: a periodontal concept for reconstructive dentistry. Periodontal Practice Today. 2007;4(3).

2. Lee EA. Aesthetic crown lengthening: classification, biologic rationale, and treatment planning considerations. Pract Proced Aesthet Dent. 2004 Nov;16(10):769-78.

3. Makigusa K. Histologic comparison of biologic width around teeth versus implant: The effect on bone preservation. J Implant Reconstr Dent. 2009;1(1):20-4.

4. Jorgić-Srdjak K, Plančak D, Maričević T, Dragoo MR, Bošnjak A. Periodontal and prosthetic aspect of biological width part I: Violation of biologic width. Acta Stomatologica Croatica. 2000;34(2):195-7.

5. Nugala B, Kumar BS, Sahitya S, Krishna PM. Biologic Width and its importance in periodontal and restorative dentistry. J Conser Dent: JCD. 2012 Jan;15(1):12.

6. Khuller N, Sharma N. Biologic width: Evaluation and correction of its violation. J Oral Health Comm Dent. 2009;3(1):20-5.

7. Newman, Takei, Klokkevold. Carranza's Clinical Periodontology 10th ed. Philadelphia: Saunders, Elsevier Publishing; 2006:1050-1069.

8. Jotkowitz A, Samet N. Rethinking ferrule-a new approach to an old dilemma. Br Dent J. 2010;209(1):25.

9. Hempton TJ, Dominici JT. Contemporary crown-lengthening therapy: a review. The J Am Dent Assoc. 2010 Jun 1;141(6):647-55.

10. Padbury A, Eber R, Wang HL. Interactions between the gingiva and the margin of restorations. Journal of clinical periodontology. 2003 May 1;30(5):379-85.

11. Uddin M, Mosheshvili N, Segelnick SL. A new appliance for forced eruption. New York State Dent J. 2006 Jan;72(1):46.

12. Danesh M. Surgical crown lengthening building a solid foundation for restorative excellence. Australasian Dent Pract. 2012:58-60.

13. Brandão RC, Brandão LB. Finishing procedures in Orthodontics: dental dimensions and proportions (microesthetics). Dent Press J Orthodont. 2013;18(5):147-74. 